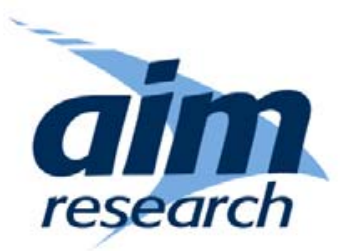

Advanced Institute of Management Research

\title{
Offshoring of business services and its impact on the UK economy
}

\section{November 2004}

Laura Abramovsky AIM, Institute for Fiscal Studies Rachel Griffith Mari Sako

AIM, Institute for Fiscal Studies AIM, Said Business School, Oxford 


\section{EXECUTIVE SUMMARY}

This Briefing Note considers recent trends in specialisation, outsourcing and offshoring of business services.

Specialisation within a firm happens when a firm organises an activity in a specialised unit, for example, when a firm moves payroll activities out of the back office of a factory, and into a specialised payroll office. Outsourcing is specialisation outside the firm. This occurs when firms opt to 'buy' rather than 'make' in-house. Outsourcing involves greater specialisation as firms switch from sourcing inputs internally to sourcing them from separately owned suppliers. Offshoring occurs when firms move production overseas - either its own specialised unit or outsourced services.

Business Services are services that are provided to other business, rather than directly to the public. They include Computer Services, Professional Services (Legal, Accountancy, Market Research, Technical, Engineering, Architectural, Advertising and Consultancy), Research and Development, as well as other services such as Labour Placement Agencies and Call Centres.

The findings in this Briefing Note, which are significant for thinking about business practice and public policy, are:

Business services have accounted for over $50 \%$ of job growth in the UK over the past two decades.

In the 1980s, business services were not very significant as a separate industry. Employment in UK business services grew by $92 \%$ or $1.9 \mathrm{~m}$ jobs between 1984 and 2001. This accounted for over half of the total growth in jobs. In 2002, a total of $4 \mathrm{~m}$ people were employed in this sector, accounting for around 1 in 7 jobs in the whole economy.

UK production of business services also grew significantly faster than the rest of the economy over the last two decades. This has been driven mainly by increased demand from UK companies for UK-produced business services. The business service sector is now substantially bigger, in terms of value added, than it was two decades ago.

More business services are purchased from the UK than the UK purchases from overseas; i.e. we have a trade surplus in business services, and it has been growing.

The growth in demand for UK-produced business services has come mainly from UK-based firms. UK businesses are now outsourcing a 
substantially greater proportion of service activities than they did two decades ago. This domestic outsourcing has played a more important role in the growth of business services than demand from foreign-based businesses.

While there has undoubtedly been an increase in UK-based firms sourcing business services offshore, it is small relative to the increase in total output of business services. This shows up in the trade statistics: although the UK has rapidly increased both its imports (UK firms buying foreignproduced services) and exports (foreign firms buying UK-produced services), export growth has outstripped import growth. The UK has a substantial trade surplus in all business service sectors except one small industry. Figures for the latest 12 months suggest that the rate of growth may have slowed.

Between 1995 and 2001, exports of business services grew from $£ 11$.7bn to $f 31.7 \mathrm{bn}$ in nominal terms while imports grew from $f 6$ bn to $£ 14 \mathrm{bn}$. This has given the UK and increasing trade surplus in business services. This contrasts with an increasing deficit in trade in manufactured goods over the last two decades. But while trade in business services is increasing, it is still very small compared with trade in manufactured goods.

Most Business Service industries in the UK have experienced continued job growth.

The fact that UK firms are increasingly sourcing business services offshore and foreign firms are increasingly sourcing business services in the UK may affect the total number of jobs in the UK, the type of jobs, the skills needed to do these jobs and the distribution of these jobs across regions and across people.

The highest profile concern has been about job losses from sourcing IT software and services in India. It is hard to get precise numbers of jobs relocated abroad, and thus to tell how important this is for the UK economy. But looking at UK job growth, particularly in call centres, in combination with the number of jobs in India serving foreign clients shows that potential UK job losses from sourcing business services abroad are pretty small compared with total job creation in business services.

The fastest growing sectors were Computer and related activities, which more than tripled in size between 1984 and 2002, and Other business activities, which doubled. Renting of machinery and equipment grew by $59 \%$ and Legal, technical and advertising grew by $71 \%$. Research and development was the only sector not to grow, with employment declining slightly, by $4 \%$ between 1984 and 2001. Growth in the most recent years has slowed down somewhat.

This growth has included in call centres, where the latest figures show that over half of the UK call centres sampled have increased the numbers 
of staff employed. The UK currently employs around 400,000 people in call centres.

UK productivity in Business Services has caught up with other G5 countries. We have substantially closed the productivity gap between the UK and the US, Germany and France in business services. This occurred while employment in the sector grew.

Between 1984 and 2001, the difference between UK and US labour productivity (the productivity gap, as measured by value-added per hour worked) in two high-skilled sectors - Computer Services and Professional Services - was effectively eliminated.

In 1984, US productivity in Computer Services was over twice as high as in the UK, while in 2001 it was only 10\% higher. In Professional Services it was $80 \%$ higher, and is now at the same level.

This simultaneous increase in employment and productivity contrasts with an earlier productivity improvement in manufacturing, which was achieved in large part through employment cuts. 


\section{INTRODUCTION}

Hardly a day passes without news of a new offshoring deal. The vast majority of newspaper reports focus on 'exporting jobs', giving the impression that the UK economy has been suffering from a loss of competitiveness in business services. But what has been the economic impact on the UK economy of increased international trade in services? Has offshoring to low-cost locations such as India and China harmed the UK? And how is the outsourcing and offshoring of business services affecting the performance of UK service sectors relative to the US and Europe? This Briefing Note provides answers to these questions by analysing official statistics at a disaggregated level.

Despite the hype in the media and some policy attention to ward off protectionist pressures in the $\mathrm{UK}^{1}{ }^{1}$ there is still little empirical research on the extent of service outsourcing/offshoring and its impact on the UK economy. This study is concerned with both outsourcing and offshoring. We begin by clarifying what is meant by outsourcing, offshoring, and business services.

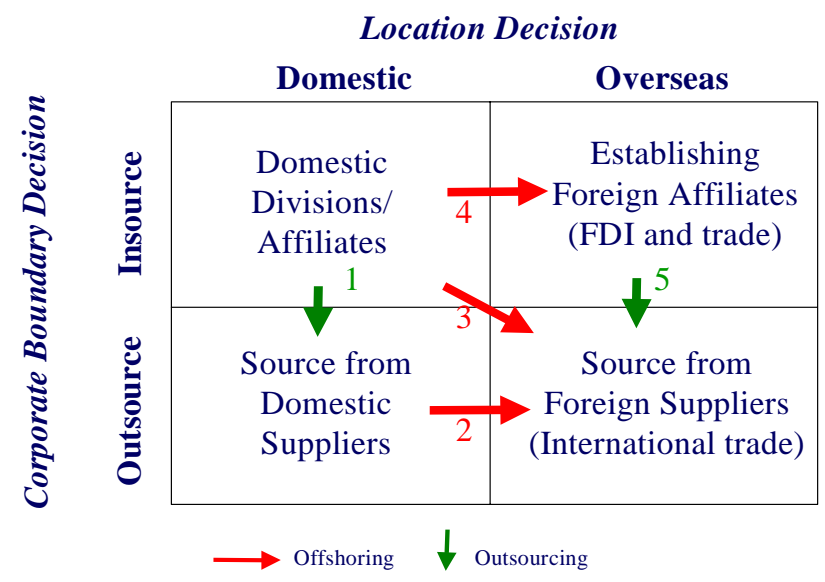

Specialisation within a firm happens when a firm moves an activity to one of its own specialised production units. Outsourcing is specialisation outside the firm. This occurs when firms opt to 'buy' rather than 'make' in-

\footnotetext{
${ }^{1}$ An analysis of newspaper and magazine articles on outsourcing and offshoring in the UK using FACTIVA indicates that the number of articles rose from a mere 6 in November 2002 to 54 in October 2004. Secretary of State for Trade and Industry, Patricia Hewitt, stated that the UK would not pass protectionist legislation (see Financial Times 5/3/2004).
} 
house. That is, outsourcing involves greater specialisation as firms switch from sourcing inputs internally to sourcing them from separately owned suppliers. Offshoring occurs when firms move production overseas. This could be to serve foreign markets - for example to substitute for exports or to import overseas produced inputs for use back in the UK. This study focuses on sourcing inputs offshore and on specialisation within the UK.

There are three separate trajectories towards offshoring, as shown in the table above. First, companies may already be outsourcing (Arrow 1), but decide to switch from a domestic supplier to a foreign supplier (Arrow 2). Second, companies may be making the decisions to outsource and to offshore to a foreign supplier simultaneously (Arrow 3). Third, companies may source from overseas locations by establishing foreign affiliates (Arrow 4). Switching the source from an overseas affiliate to a foreignowned supplier (Arrow 5) may occur, but is not part of this study. This study analyses offshoring (all three red arrows) and also specialisation within the UK, that is domestic outsourcing (i.e. green Arrow 1) plus when a firm decides to fragment its activities within its boundaries in the UK (this happens within the top left hand side cell in the table above).

Outsourcing and offshoring have been part of the staple diet of corporate activities for a long time. What is new is that they are occurring increasingly in business services. Traditionally services have been thought of as non-tradable. Technological developments mean that it is becoming increasingly easy to provide them from afar. Services can be divided into two categories, those used by individual consumers and those used by businesses and public administration. Business services refer to this latter category, and include such activities as computer hardware and software consultancy, professional services, and other more diverse activities such as labour placement agencies and call centres (see Box 1 for more detail on the relative importance of these sub-sectors within Business Services).

Business services are among the most dynamic sectors in the UK in terms of employment. Total employment in the UK grew by $14 \%$ or 3.6 million jobs between 1984 and 2001. Business services accounted for half of that growth, or 1.9 million jobs. The fastest growing sectors were Computer and related activities, which more than tripled in size (employment increased by 251\%), and Other business activities which doubled (employment grew by $101 \%$ ). Renting of machinery and equipment grew by $59 \%$ and Legal, technical and advertising grew by $71 \%$. Research and development was the only sector not to grow, with employment declining slightly, by 4\% between 1984 and 2001. 


\section{Box 1: Business Services Defined}

Services can be divided into two categories, those used by individual consumers and those used by business firms and public administration. Business Services in government statistics refer to this latter category, and can be divided further into IT services and a much larger and growing sector called IT-enabled services. IT services consist of hardware and software consultancy, maintenance and repair of computers, and data processing and database activities. IT-enabled services include professional services (Legal, Accountancy, Market Research, Technical, Engineering, Architectural, Advertising and Consultancy), but also other more diverse activities such as labour placement agencies, renting of machinery, R\&D, and call centres.

In the 1980s, business services were not a very significant industry, since most of the tasks now outsourced to business services firms or plants were carried out within manufacturing or non-specialised plants or offices.

Figure 1: What is business services?

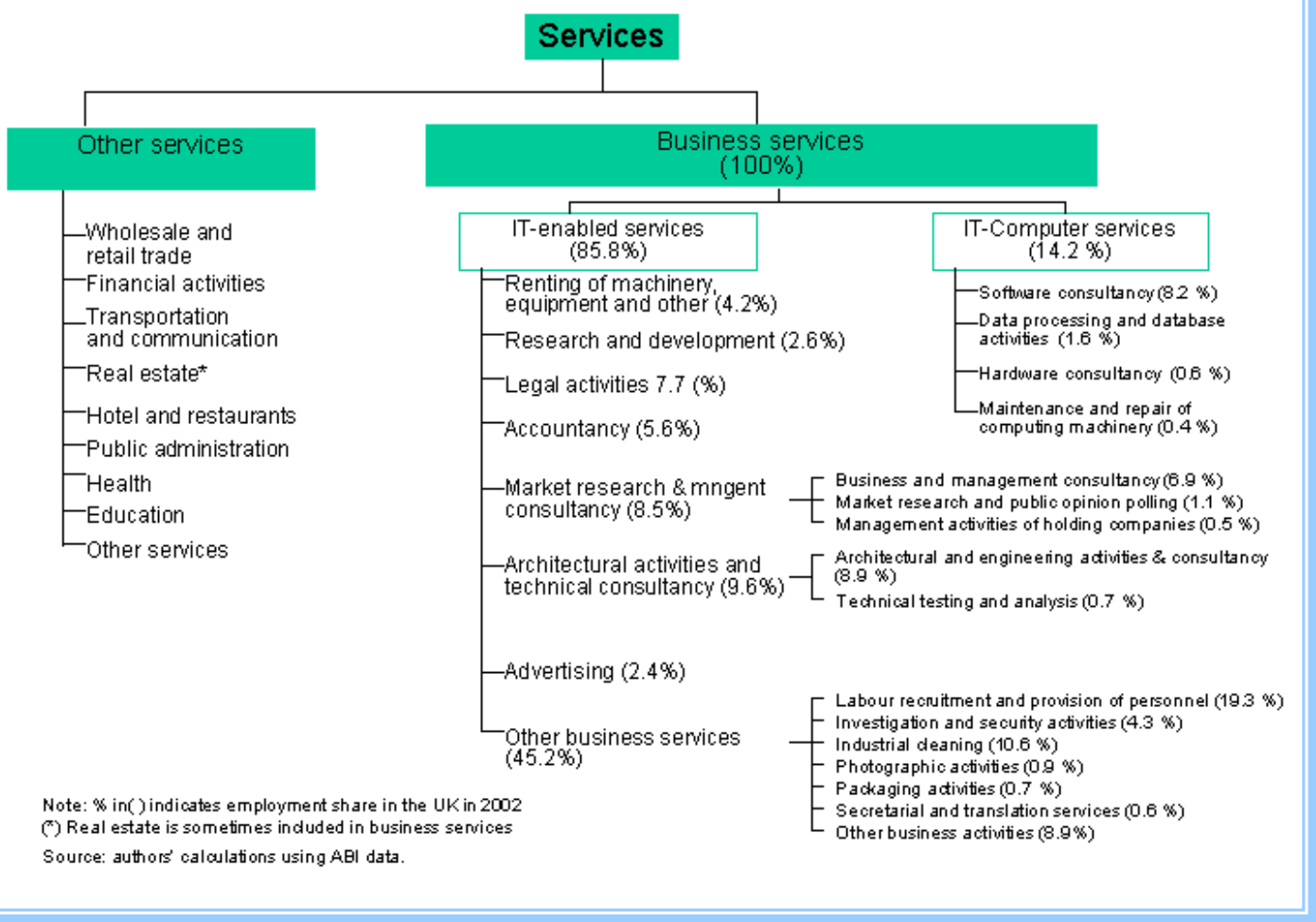


This Briefing Note begins by providing some figures on the extent to which trade in business services has increased and how this has affected the UK in the last two decades. We then put this in the context of general trends in specialisation and outsourcing towards business services within the UK. The penultimate section describes what impact this has had on the UK economy. A final section concludes by discussing ideas for further research. 


\section{OFFSHORING}

\subsection{More business services are purchased from the UK than the UK purchases from overseas}

We begin by looking at how much business services UK-based firms source offshore and how much foreign firms source from the UK. It is difficult to get exact figures on these transactions. The best source of information over a long time period is trade data. ${ }^{2}$ When UK-based firms source inputs offshore this shows up as an import. When foreign-based firms source inputs from the UK this shows up as an export. Although trade figures refer to total imports and total exports of goods and services used by both individuals and businesses, in business services pretty much all imports and exports are for intermediate use by businesses. ${ }^{3}$

Even though it has grown substantially, trade in business services is still small compared to trade in manufacturing goods. In the UK, trade in manufactured goods accounted for around

\section{Box 2: UK Firms Offshoring}

British Airways was an early offshorer. In May 2002 it created call centres in India to handle flight booking and processing. Recent offshoring deals have featured UK-based financial firms.

Royal and SunAlliance announced in October 2004 its decision to outsource 1100 jobs to India, adding to the estimated 50,000 posts already offshored from the UK in the past two years.

Aviva transferred 2350 jobs from Britain to India inOctober 2003, and doubled its jobs export to 7000 in October 2004.

Barclays Bank is restructuring and relocating jobs overseas, and has signed an offshoring deal with the UNIFI union, agreeing to minimize job losses and the consequent impact of people and communities. HSBC and Prudential announced that they would offshore to India.

Non-financial examples of offshoring include Adecco, the UK labour recruitment agency, which opened an office in India to supply workers to call centres located in the region. Reuters opened a new centre in Bangalore to source financial news. It plans to eventually employ up to 15,000 people in India, or 10 per cent of its workforce.

\footnotetext{
${ }^{2}$ Offshoring may comprise establishing affiliates in other countries, but we are going to look only at trade data and not to FDI.

${ }^{3}$ For 1995, the input-output data separate out the different users of imports and we can calculate how much of business services imports are used by producer industries and how much by final consumers. In that year, $97 \%$ of imports of business services were accounted for by intermediate imports. The share for manufacturing is much lower: only $55 \%$ of manufacturing imports were consumed as inputs, whilst the rest were final goods sold directly to consumers.
} 
three-quarters of total imports and two-thirds of total exports. Business services accounted for only $£ 1$ in $£ 20$ of imports and just over $£ 1$ in $£ 6$ of exports. Sourcing of manufactured goods overseas has been taking place for longer and is still much larger in magnitude than sourcing of business services. $^{4}$

Total imports have grown over the past two decades. Imports of services have grown particularly fast, and imports of business services have grown even faster. This has raised fears of UK job losses resulting from the sourcing of business services offshore. See Box 2 for some examples of UK-based firms that decided to move their activities abroad. There are also some companies (e.g. Alliance \& Leicester, Nationwide, and the Royal Bank of Scotland) that were reported to have considered sourcing offshore, but decided against it.

The ratio of imports of business services to UK GDP gives us an indication of the intensity with which UK-based firms are sourcing business services abroad. In 2001, this ratio was around $2 \%$, higher than two decades before, but still very small. Also, it is informative to look at how imports of business services have grown compared to UK production of business services. This gives us an idea of how important competition from imported business services is for the domestic industry. This ratio declined slightly from 1995 to 2001 , to around $8 \%$ in 2001, compared to $50 \%$ in manufacturing in the same year. This suggests that, while imports of business services grew, they

\section{Box 3: Global Employee Services Outsourcing}

IBM signed a ten-year $\$ 400$ million deal with the Proctor \& Gamble Company (P\&G) in 2003 to manage $P \& G$ 's employee services. As a result, IBM Business Consulting Services supports 98,000 P\&G employees in nearly 80 countries, providing services that include payroll processing, benefits administration, compensation planning, expatriate and relocation services, travel and expense management, and human resources data management.

P\&G decided to outsource these activities in order to improve responsiveness in services and reduce HR costs through business process transformation and technology integration.

Approximately $800 \quad P \& G$ employees that used to manage these services in-house have moved to join the IBM Human Resources Business Transformation Outsourcing (HR BTO) team. The IBM team for P\&G operates primarily out of three HR shared service delivery centres in Newcastle, England; San Jose, Costa Rica; and Manila, Philippines. Thus, the UK features as a significant offshoring base in this global HR outsourcing deal.

Source: IBM Press Release

\footnotetext{
${ }^{4}$ See Campa, J. and L. Goldberg (2004), “The evolving external orientation of manufacturing industries: evidence from four countries”, NBER Working Paper No. 5919 (Cambridge, Massachusetts: Natioanl Bureau of Economic Research).
} 
increased at a slower rate than domestic production of business services.

The increase in trade in services has affected not only the UK, but other countries as well. Just as UK firms are sourcing from overseas, foreign firms can source services from the UK. As we mentioned earlier, when foreign firms source from the UK this shows up as exports. Box 3 illustrates a case where the UK was chosen as a base to provide business services to foreign-owned global firms.

As with imports, exports have also grown over the past two decades. ${ }^{5}$ Exports of services have grown particularly fast, and exports of business services have grown even faster. Exports of business services grew at a similar rate to UK production of business services over 1995 to 2001.

Figure 2: Level of imports and exports in Business Services

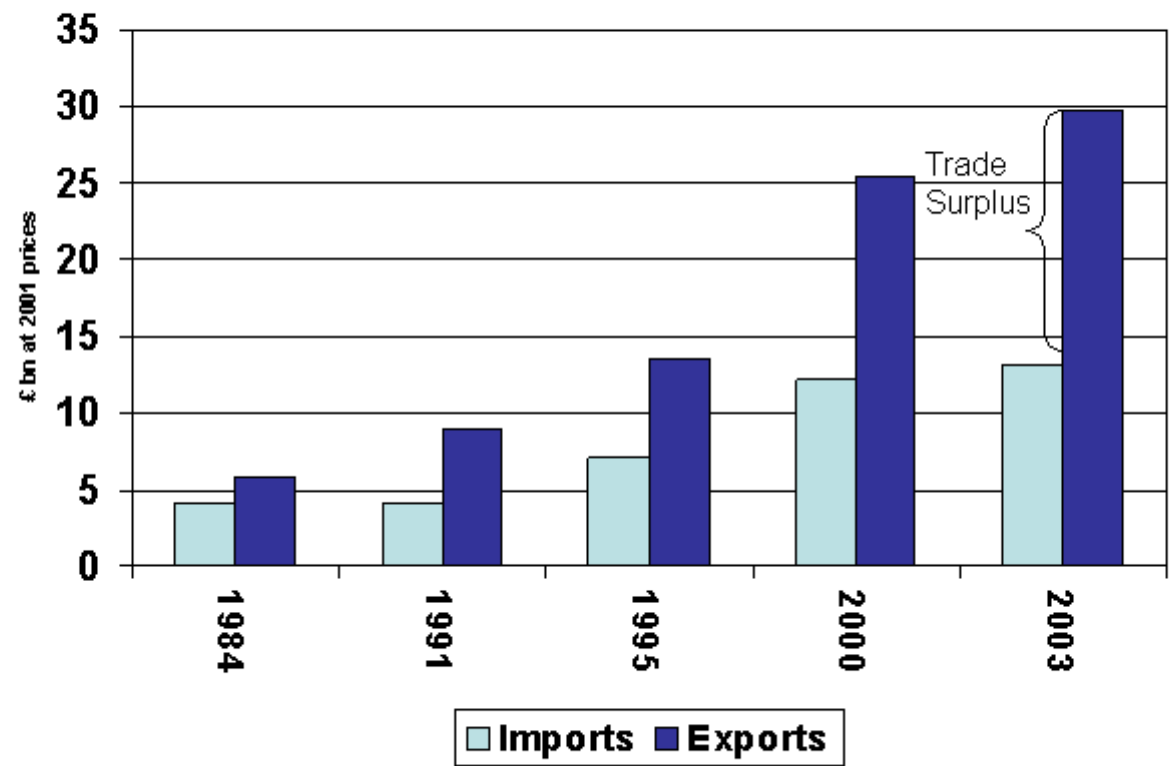

Note: auxiliany fin ancial senvices and real estate are induded in 1984 but exduded in all other ye ars. Whe used value added deflators. Source: authors' calculations using ONS Input Qutput Tables for 1984 and Bal ance of Payments data for all other years.

Figure 2 shows the UK's trade position in business services from 19842003. ${ }^{6}$ The UK has always had a trade surplus - exports are greater than imports. This means that foreign firms have always sourced business services from the UK to a greater extent than UK-based firms have

\footnotetext{
${ }^{5}$ Exports include UK-based firms supplying services to foreign-based firms or final consumers. If a UK-based firm decides to establish affiliates overseas to serve foreign markets as a substitute for exports, these would show up as a decrease in exports, and an increase in FDI.

${ }^{6}$ All trade figures are deflated using GDP deflator based in 2001. GDP deflators control for common inflation in the economy but will not reflect changes in the relative cost or quality of services or imports. The picture looks very similar if we use industry level deflators.
} 
sourced business services from abroad. Although both imports and exports have grown during this period, over 1995 to 2003 export growth outstripped import growth, leading to a trade surplus of over $£ 15$ billion in 2001. The UK now exports more than twice as much business services as it imports. In contrast with business services, the UK imports more manufactured goods than it exports, so has a trade deficit.

To summarize, while there has undoubtedly been an increase in UK-based firms sourcing business services offshore, and this has meant some output and some jobs moving abroad, this is still small compared to the production of business services in the UK. Furthermore, the net flow of trade for the UK in business services has been in the opposite direction. Foreign-based firms source business services from the UK to a greater extent than UK firms source abroad. Overall increased trade in business services has led to an increased trade surplus for the UK. ${ }^{7}$

\subsection{How does the UK position compare to other G5 countries?}

In 2002, the UK was the second largest world exporter of business services after the US, and the UK accounts for an increasing share of world total exports of business services.

The US and France also had a trade surplus in 2002, although France's trade surplus was much smaller than the UK's. Germany and Japan had a trade deficit (they imported more than they exported) in other commercial services.

The UK's trade surplus is larger than the US in absolute terms, and, if considered relative to the size of the economy, appears even larger.

\footnotetext{
${ }^{7}$ Note that the UK may well have benefited from trade, even if it had a trade deficit. A country may have a trade deficit in some industries and a trade surplus in others, according to which activities the country is specialised in. See section 5 for a discussion of the economic impact of trade.
} 
Figure 3: Trade surplus in business services, 2002

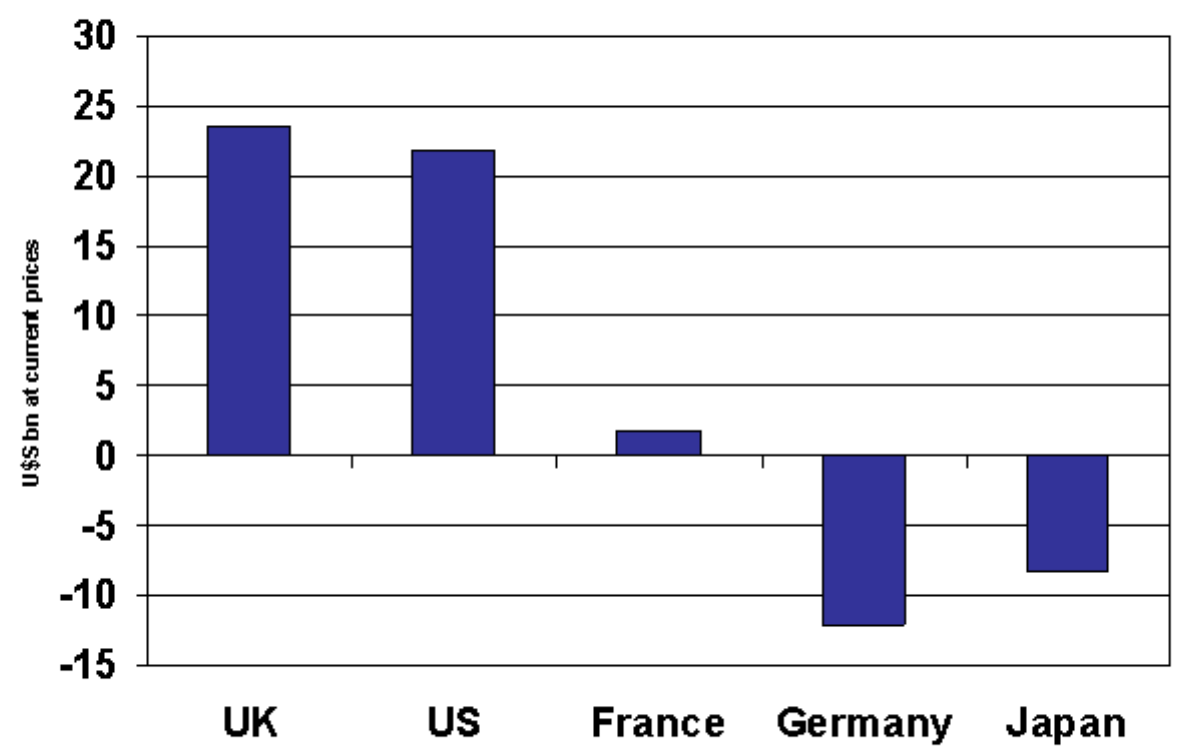

Source: authors' calculations using IMF Balance of Payments Statistics Yearbook. This indudes IMF industries classifications "business senvices" plus "computer senvices".

Most trade in business services is between developed countries. While sourcing business services from developing countries has undoubtedly increased, it is still relatively small. In 2002, almost $70 \%$ of exports of other commercial services (which include business services plus financial services) were accounted for by thirteen developed economies. Of developing economies, Hong Kong-China and India were the largest exporters. $^{8}$

\footnotetext{
${ }^{8}$ WTO (2003) op cit., Table IV.80. In 2002 India was the sixth largest exporter of business services, though it imports as much as it exports. China had a trade surplus in business services. See Amiti and Wei (2004).
} 


\subsection{In which types of Business Services does the UK have a trade surplus?}

This sub-section takes a closer look at the UK trade patterns in business services, by examining trade in each of the industries within the business services sector. In 2001, there was a positive trade balance in all sectors except rental of machinery (which is a small sector, accounting for $4 \%$ of employment of business services, as shown in Figure 1). In all industries the trade surplus increased between 1995 and 2001 in absolute terms. Figure 4 shows the trade gap in the industries within business services. ${ }^{9}$

Figure 4: Trade surplus in business services sectors

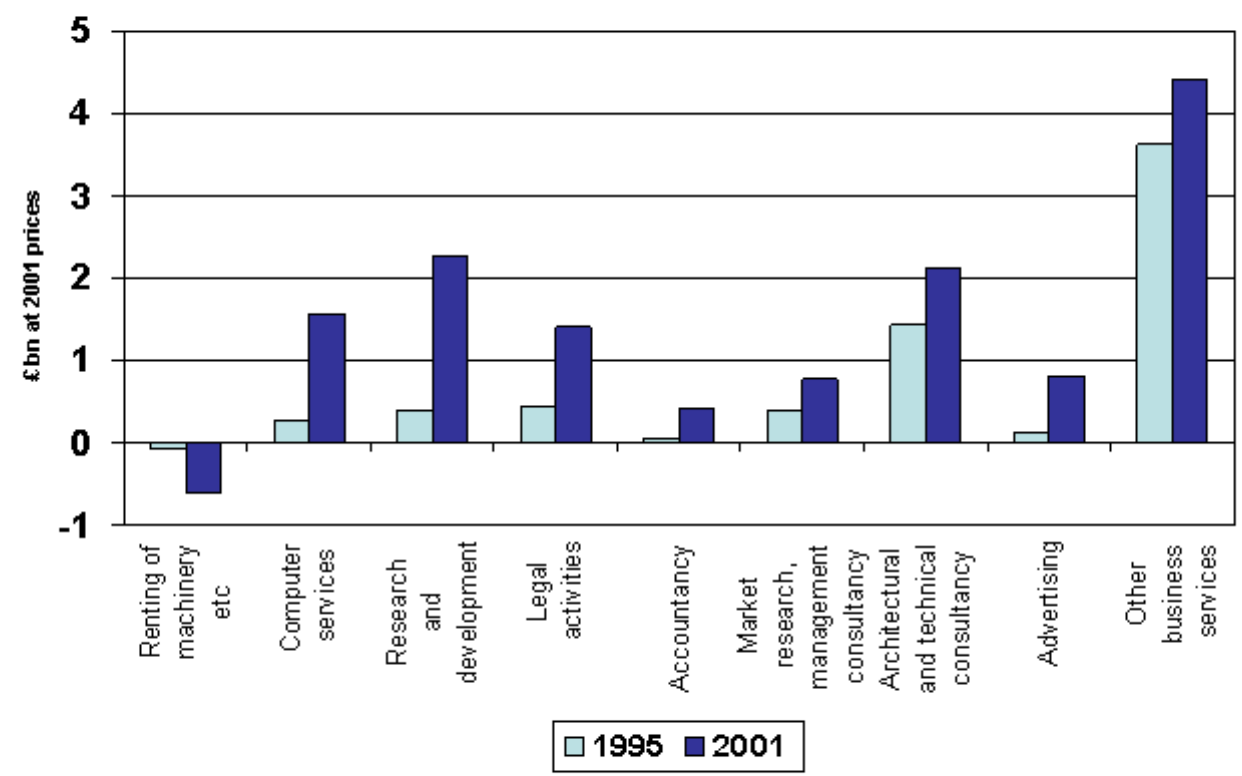

Source: authors' calculations using Input Output data published by ONS.

By 2001, the top five sectors in terms of their positive trade balance were: (1) other business services, (2) R\&D, (3) architectural activities and technical consultancy, (4) computer services, and (5) legal services. These five sectors together accounted for $90 \%$ of the total trade surplus in UK business services in 2001.

\footnotetext{
${ }^{9}$ All trade figures are deflated using GDP deflator based in 2001. GDP deflators control for common inflation in the economy but will not reflect changes in the relative cost or quality of services or imports. The picture looks very similar if we use industry level deflators.
} 
Other business services ${ }^{10}$ showed the biggest trade surplus in both years, not surprisingly as it was the biggest industry within business services, accounting for $45 \%$ of employment within this sector. The trade surplus in 'Other business services' accounted for a third of the trade surplus in total business services in 2001. However, the trade surplus in this industry grew slower than the total, so it accounted for a smaller share of the total than in 1995 (when it accounted for more than half of the total trade surplus in business services). Imports in other business services increased faster than exports. This meant that there was a faster increase in UKbased firms sourcing these services abroad than foreign firms sourcing from the UK, although the balance is still positive. As an example, Box 3

\section{Box 4: Globalisation of R\&D}

Corporate $R \& D$ used to be concentrated in the home market near the head office. Now companies are redistributing not only their design and development activity, but also basic and applied research across global R\&D networks. According to a worldwide survey of 104 senior executives conducted by the Economist Intelligence Unit, 70\% of respondents reported that their company already employed $R \& D$ talent overseas, and $52 \%$ of executives plan to increase their investments in overseas research in the next three years. When asked where they would spend the most on $R \& D$ in the next three years, 39\% said China, 29\% the US, 28\% India, 24\% the UK, and $19 \%$ Germany. Thus, the UK ranked fourth as the favourite location for $R \& D$ outsourcing. The popularity of China and India as R\&D locations is striking, particularly as there are signs that these emerging markets are climbing up the $R \& D$ value chain, undertaking not just product design but high-end $R \& D$.

Of the many possible motivations for developing a global corporate $R \& D$ network, three stood out as priorities for the companies surveyed. The first is a search for global talent, locating where it is possible to exploit pools of skilled labour, normally close to major research universities and labs. The second is to meet demand in fast-growing markets, by working across time zones and distance, not only to respond quickly to local needs but to get ahead in the $R \& D$ race. The third motivation is to cope with cost pressures, as $R \& D$ costs are escalating in some high-tech industries like pharmaceuticals. The report, however, acknowledges that savings from cheap labour are partially offset by the costs of coordinating R\&D across multiple countries, whether R\&D is internal to a global corporation or outsourced to locally owned offshore facilities.

Source: Economist Intelligence Unit (2004) Scattering the seeds of invention: the globalization of research and development.

illustrates the case of a UK-based firm that provides personnel management services to firms located abroad.

\footnotetext{
${ }^{10}$ See Figure 1 for a description of what activities comprised Other business services. Unfortunately, there is no information to disaggregate trade flows within Other business services.
} 
Research and development showed the second biggest trade surplus in 2001 . It accounted for $17 \%$ of the total trade surplus, compared to only $3 \%$ of employment in business services. The increase in the trade surplus of R\&D products was associated with an increase in exports, which more than doubled, while imports decreased slightly. There was an increase in foreign firms sourcing R\&D from the UK, while UK-based firms sourcing $R \& D$ abroad remained quite stable.

In 2001 almost $40 \%$ of UK-produced R\&D services were exported, double the amount in 1995 (21\%). ${ }^{11}$ Box 4 discusses this trend in the globalisation of R\&D. The Box highlights the fact that globalisation of $R \& D$ is both within global corporations and through firms sourcing offshore to $R \& D$ firms operating in other countries.

The industry with the third biggest trade surplus was architectural activities and technical consultancy. This accounted for around ten percent of employment and 16\% of the trade surplus in business services in 2001. Imports and exports grew at the same pace as the trade surplus and output. Hence, the export orientation and import penetration of this industry remained stable from 1995 to 2001.

\section{Box 5: Legal Outsourcing}

The legal profession has a conservative image of integrity and caution. Thus, it is not surprising that outsourcing of legal services is happening at a much slower pace than in other sectors. Forrester projects that almost 40,350 legal jobs in the US will be outsourced by 2015, amounting to nearly 8 per cent of the total employed in the field. Outsourcing and offshoring of legal services started with standardized administrative tasks such as document editing and proofreading. More recently, Indian providers of legal services have begun to undertake more skill-intensive work such as litigation research that used to be carried out by paralegals in-house, and intellectual property work involving patent research, analysis, and drafting of patent applications. Not surprisingly, large established law firms appear to be followers rather than leaders in the outsourcing drive, as medium-sized specialist firms, such as those in intellectual property, have a greater need to economize on internal resources to focus on their core competency.

Source: Financial Times 'Caseload grows for advocates in absentia', 4 October 2004.

Computer services showed a trade surplus of over $£ 2.3$ bn in 2003 . This accounted for $14 \%$ of the total trade surplus of business services. Exports of computer services from the UK grew faster than imports into the UK up

\footnotetext{
${ }^{11}$ The import penetration (ratio of imports to output) diminished from $13.4 \%$ in 1995 to $8.7 \%$ in 2001 .
} 
to 2003. However, both grew slower than output of computer services, hence export orientation and import penetration decreased.

Finally, legal services had the fifth biggest trade surplus. It accounted for $11 \%$ of the trade surplus of business services and $7.7 \%$ of employment. Exports grew faster than imports and UK output of legal services over 1995 to 2001. Box 5 discusses recent trends in offshoring of legal services. 


\section{OFFSHORING IS PART OF A MORE GENERAL TREND TOWARDS SPECIALISATION AND OUTSOURCING}

Offshoring is one form of specialisation, but not the only one. Specialisation occurs when firms concentrate their activities in producing intermediate goods or services, and are separated from the location of final production. In this way, firms organise tasks in more specialised ways. When the specialised operations are owned by the same firm, this is called insourcing. When they are owned by another firm, then it is outsourcing.

What are the economic and strategy reasons for this? Insourcing decisions may be related to efficiency gains through returns to scale. Outsourcing decisions are more related to the incentives that producers and suppliers have for efficiency and innovation. They may also be related to returns to scale. Sourcing offshore could involve insourcing or outsourcing. Reasons in these cases are usually related to costs, access to technology or access to scarce resources (such as skilled labour).

What factors are driving the increase in sourcing offshore? In part it reflects

\section{Box 6: Corporate Strategy in Outsourcing Business Services}

How to capture maximum value in the supply chain has long been a philosopher's stone in corporate strategy. Outsourcing is simply the most recent fad in this central question, but has been going on for a long time. What is new, however, is the opportunity that information and communication technology (ICT) provides in transforming the way we think about the service value chain, and more specifically the business process value chain. In the past, global outsourcing was possible in manufacturing, but not in services, because production and consumption had to be co-located for most types of services. ICT enables the disintegration of the value chain in services. This happens either because production and consumption can now be separated through the standardisation of process and the capacity for data storage (e.g. for legal services, payroll processing, medical diagnosis, etc.), or because geographical distance is not a barrier for the simultaneous production and consumption of services (e.g. through call centres). Consequently, greater specialisation is facilitated by ICT. This has led to new openings for existing IT companies (such as Hewlett Packard, IBM, and EDS), start-ups, and professional services firms (such as Accenture) to provide not just IT services but also IT-enabled services. 
increasing specialisation more generally - firms are reorganising themselves, both internally and externally. Rather than back office activities taking place within each plant, they are now centralised within the firm, or outsourced to a specialist firm. For example, Procter and Gamble Company ( $P \& G$ ) used to do their own payroll processing, benefits administration, and compensation planning. But now, IBM Business Transformation Outsourcing office manages these services on behalf of P\&G (see Box 3).

Specialisation has in part been fuelled by the lower cost and increasing importance of information technology, which decrease the cost of coordinating activities located in different places. Once activities are centralised within a country they can more easily be moved abroad. Geographic proximity is no longer as important with cheaper phones, email and video conferencing (see Box 6). Other technology changes, such as how products are created, can also change the way firms may best organise. Additionally, greater competitive pressures, created by both increased globalisation and technological advances, have meant there is a greater need for firms to specialise in order to remain competitive or to take advantages of economies of scale.

While UK producers are buying intermediate services overseas (e.g. by locating call-centres in India), the UK also sells intermediate goods and services to overseas producers (e.g. financial and business services). In this section we provide analysis to demonstrate the relative significance of offshoring (from and to the UK) in the context of broader specialisation trends in the UK in recent years.

\subsection{Offshoring in the context of domestic outsourcing}

Over the past two decades Business Services accounted for a large part of growth in the UK and other developed economies. How much of the change in output of business services was associated with increasing specialisation within the UK? How much was associated with changes in exports (foreign-based firms sourcing from the UK). How does this compare to changes in imports (UK-based firms sourcing abroad)? In this section we provide some answers to these questions.

There has been rapid growth in the business services sector in the UK, accounting for around one-third of total UK output growth between 1984 and 2001 . Over half of this ${ }^{12}$ was accounted for by other UK-based firms' purchases of business services (as opposed, for example, to direct purchases by consumers or purchases by foreign-based firms); and of this, one-third ${ }^{13}$ was due to these firms increasingly using business

\footnotetext{
${ }^{12}$ Around $£ 1$ in every $£ 6$ of total UK output growth.

${ }^{13}$ Around $£ 1$ in every $£ 18$ of total UK output growth.
} 
services produced in specialised plants. These figures suggest a big increase in the extent to which UK firms are restructuring business services, either by specialising within the firm, or by outsourcing to other UK firms.

How do these figures compare to changes in exports and imports of business services? Around one tenth of the growth in UK-produced business services was due to increases in the purchases of these services by foreign-based firms (exports). In comparison, the change in UK-based firms purchases of foreign-produced business services (imports) represented only about half that amount. This is telling us that specialisation within the UK has been more important for business services growth than sourcing offshore. It also suggests that increasingly more business services are purchased from the UK than the UK purchases from overseas.

The precise figures are shown in Table 1.

Table 1: Business Services share of UK output growth, 1984-2001

Share of total growth in

UK-produced output

(1) Purchases of business services by UK-based firms

$19.5 \%$

(2) of which specialisation and outsourcing

$6.5 \%$

(3) Purchases of business services by foreign-based firms (exports)

$3.7 \%$

(4) Other purchases of business services

$8.8 \%$

(5) Total purchases of business services $=(1)+(3)+(4)$

$32.0 \%$

(6) Purchases of foreign-provided business services by

UK-based firms (imports)

$1.7 \%$

\section{Notes:}

(1) Share of the total increase in UK output that was accounted for by increased purchases of business services by other businesses in the UK, including capital goods. The increase in purchases could be because the purchasing firms have grown in size, and so now need more business services, or because they now use these specialised business services more intensively than before.

(2) is part of (1). It is the increase in firms' purchases of business services that is driven by an increased intensity of usage of business services produced in specialised plants or offices, in order to produce the same amount of output that they were producing in 1984.

(3) Share of the total increase in UK output that was accounted for by an increase in purchases of business services by foreign-based firms, that is an increase in exports of business services.

(4) Share of the total increase in UK output that was accounted for by changes in purchases of business services by consumers and government.

(5) Total is the sum of rows (1), (3) and (4). It is the share of the total increase in UK output accounted for by Business Services.

(6) Final row is growth of imports by sector as a proportion of growth in total output.

See the Technical Appendix for details on the decomposition analysed here. 
To make this more concrete consider an example. A bank has back office employees in each branch that answer the phone. It decides to put them together in a call centre. They can choose to set this up themselves or to buy the service from another firm. In either case we will see an increased use of call centres by banks, because the bank has separated their activities into banking and call centre. This will show up in Table 1 as "specialisation" in row (2).

If subsequently the bank (which is now already using a specialised call centre) becomes successful and grows it will purchase more services from the call centre. If the amount of purchases it makes grow in proportion to the growth in the size of the bank's business, then this will show up in the row (1). That is, it is an increase in demand for business services, without a change in the intensity of its usage of call centres. Finally, if the bank decides to move its call centre to India this will show up in row (6); it is importing this service. If, on the other hand, the bank discovers it is very good at running its call centres, and decides to provide this service to firms located outside the UK, this will show up in exports, in row (3).

\section{Box 7: Business Services compared to other industries}

How has specialisation affected other sectors? For many other service sectors the story looks similar - the major shift has been an increase in specialisation towards UK-produced inputs. This includes, for example, in the public sector and financial intermediation.

In manufacturing the picture is quite different. There has not been specialisation towards UK-produced inputs, and there has been an increase in imported inputs. This is reflected in the increasing UK trade deficit in manufactured goods.

To summarize, most of outsourcing and specialisation of business services have happened domestically, within the UK economy. Outsourcing that involves the importing or exporting of business services has been relatively small. However, global sourcing has accelerated, especially of services enabled by IT technology. ${ }^{14}$ Feasibility and cost reducing factors are not the only determinants of firms' global sourcing; relative quality of services, legal and cultural considerations may also enter in the decision equation as well as the cost of sourcing offshore itself.

\footnotetext{
${ }^{14}$ See World Investment Report (2004)
} 


\subsection{Who is purchasing business services?}

In the previous sub-section, we saw a big increase in specialisation in business services. But who are purchasing these services? Table 2 shows how the percentage of total business services purchased by each industry has changed from 1984 to 2001. Business services themselves are now the most important purchaser of business services. This was not the case two decades ago, when manufacturing was the biggest purchaser, followed by wholesale and retail. In 1984, services accounted for just less than half of total purchase of UK business services. By 2001, purchases by the services sector shot up to over $80 \%$ of the total. Thus, over time, service providers are demanding services as specialization increased amongst them.

Table 2: Purchasers of UK business services

\begin{tabular}{lrrrr}
\hline Industry & 1984 & 1990 & 1995 & 2001 \\
\hline Agriculture, Mining and Quarrying & $1.8 \%$ & $1.1 \%$ & $2.4 \%$ & $1.3 \%$ \\
Production & & & & \\
$\quad$ Manufacturing & $31.3 \%$ & $21.1 \%$ & $14.6 \%$ & $9.8 \%$ \\
$\quad$ Electricity, gas and water supply & $1.5 \%$ & $0.7 \%$ & $0.9 \%$ & $1.0 \%$ \\
$\quad$ Construction & $15.6 \%$ & $9.4 \%$ & $8.1 \%$ & $6.4 \%$ \\
Services & & & & \\
$\quad$ Wholesale and retail trade & $24.1 \%$ & $15.5 \%$ & $14.6 \%$ & $16.7 \%$ \\
$\quad$ Hotel and Restaurants & $1.1 \%$ & $1.9 \%$ & $1.8 \%$ & $2.1 \%$ \\
$\quad$ Transport and communication & $1.8 \%$ & $7.5 \%$ & $8.5 \%$ & $9.2 \%$ \\
$\quad$ Financial intermediation & $10.2 \%$ & $17.5 \%$ & $14.7 \%$ & $14.2 \%$ \\
$\quad$ Business Services and real estate & $8.8 \%$ & $21.2 \%$ & $21.2 \%$ & $28.3 \%$ \\
$\quad$ Public administration and other services & $3.9 \%$ & $4.3 \%$ & $13.3 \%$ & $11.1 \%$ \\
& & & & \\
Total & $100 \%$ & $100 \%$ & $100 \%$ & $100 \%$ \\
\hline \hline
\end{tabular}

Outside business services, 'Public administration and other services' and 'Transport and communication' are the other two services sectors that have increased the demand for business services very rapidly over the last two decades. Specialisation through outsourcing, therefore, is happening as much in the public sector as in the private sector. 


\section{IMPLICATIONS FOR THE UK ECONOMY}

What implications does the increasing globalisation of business services have for the UK economy, now and in the future? The overall impact will depend on many factors and may differ between the short and the long run.

UK firms are increasingly sourcing business services offshore, and foreign firms are increasingly sourcing business services in the UK.

This may affect:

- the total number of jobs in the UK;

- the type of jobs available in the UK, the skills needed to do these jobs, and the distribution of these jobs across regions and across people;

- overall welfare in the UK through the price of business services used and thus the price of final goods produced, and the amount of goods sold both in the UK and abroad;

- productivity in business services and other industries.

\subsection{What does economic theory tell us?}

In principle, the impact of increased trade in business services should not be different from the impact of increased trade in goods. Economic theory suggests that trade usually raises overall income and, in the long run, will not lead to job losses. ${ }^{15}$ However, changes in the terms of trade may affect the composition of employment. Some workers who used to produce services that are now bought cheaper from abroad may be displaced. These jobs are lost to the UK. But, it is likely that the UK will gain other jobs in areas in which the UK is relatively more productive than other countries. This results in a shift in the occupations and skills in employment in the UK, and is likely to lead to temporary job loss and to disproportionately affect employment in some regions.

Workers that lose their jobs due to import competition may take some time to find another job, for example, because they need to retrain and/or to relocate. So in the short to medium run there are likely to be job losses.

\footnotetext{
${ }^{15}$ See Dornbusch, Fischer and Samuelson (1977) and Dornbusch, Fischer and Samuelson (1980).
} 
An important point is that the gains from increased trade are disperse across the whole population of the UK, while the losses are concentrated on a relatively few people. It is important that we have effective mechanisms for redistribution and mechanisms that enable displaced workers to shift to new jobs.

This movement of workers from relatively lower to relatively higher efficiency activities should result in an increase in GDP per capita, or labour productivity. In addition, if firms pass some or all of the costsaving from cheaper inputs on to consumers, this will mean lower prices of final goods. Finally, increases in income in all countries engaged in trade would increase the total amount of demand, including for UK goods and products.

An age old issue in the economic literature is about the impact that increasing trade will have on employment and more generally welfare. Two recent papers in the J ournal of Economic Perspectives have discussed this issue in the context of current US policy. ${ }^{16}$ They discuss the fact that increasing trade in business services may change the price of exports relative to imports. This means there may be a change in how much we can get from abroad for every product we sell to foreigners. This can offset the overall income gains from trade. This has been regarded as a theoretical possibility for very large countries, but in the case of the UK, the circumstances under which this will happen are unlikely. ${ }^{17}$

In terms of productivity gains, an increase in sourcing business services abroad could affect productivity in different ways. If imports are competing with domestic activities, this could lead to gains in efficiency in the industry by driving the least efficient firms to exit the market. In addition, competitive pressure may force the remaining firms to become more efficient and increase their innovative efforts. The aggregate productivity of business services in the UK could also increase if UK business services shift their activity from lower productivity to higher productivity ones.

Specialisation towards business services within the UK could also lead to productivity growth due to gains in economies of scale and the efficiency with which these services are produced.

In terms of overall welfare, more trade in business services is likely to be a good thing (as with all goods and services), since it means lower prices for consumers if cost-savings translate to lower prices, cheaper and greater variety of inputs that allow domestic firms to increase their competitiveness and devote resources to more efficient and productive activities and also increased demand from abroad for UK output. These

\footnotetext{
${ }^{16}$ Samuelson (2004) and Bhagwati et al. (2004).

17 This could happen if the worldwide supply of the goods and services that the UK traditionally exports increases so much that there is an excess of supply in the world market and their price declines, relative to those goods and services that the UK imports.
} 
gains, however, depend crucially on the ability of the economy to react by introducing new products and processes that generate new jobs and by investing in human and physical capital as well as in innovation activities.

\subsection{What has outsourcing and offshoring meant for the UK so far?}

\section{Employment}

The big concern in the UK has been about job losses from sourcing IT software and services in India. This has been based largely on the media coverage. It is hard to get precise numbers of jobs relocated abroad, and thus to tell how important this is for the UK economy. However, looking at job growth in the UK, the increase in jobs in call centres in the UK and the number of jobs in India serving foreign clients this shows that potential job losses from sourcing business services abroad seem to be pretty small for the UK compared to total job creation in business services.

Business services are among the most dynamic sectors in the UK in terms of employment. As mentioned above, business services grew much faster than total employment, accounted for half of total growth, or 1.9 million jobs.

Data on jobs in call centres show that there is job creation in that industry as well. Of call centres participating in the IDS survey in the UK, 58\% surveyed said that there had been an increase in staff in the last year and the majority of the biggest organisations said that they also expect an increase next year. ${ }^{18}$ Of course, business services job growth could have been higher in the absence of offshoring. But this suggests that the impact of offshoring has not been too dramatic. In addition, gains in efficiency due to offshoring could have meant more jobs for the UK.

Data from the software industry in India also suggests that job losses to sourcing computer services in that country are small compared to total jobs in the computer industry in the UK. Workers in this industry in India serving

Box 8: The UK compared to the US

The US picture with respect to the importance of business services in growth is similar to the UK's. Over the period 1988-2000 most of job gains are in the service sector and in particular in business-oriented services, which include computer services, management and engineering services, labour recruitment services and other. Business-oriented services accounted for around a quarter of employment growth in this period.

Source: Goodman and Steadman (2002) foreign clients increased from

\footnotetext{
${ }^{18}$ Source: IDS Pay and Condition Report on Call Centres (2004), see appendix.
} 
152,000 in March 2000 to 505,000 in March 2004. ${ }^{19}$ Seventy percent of this increase was to serve clients based in the US. ${ }^{20}$ This leaves 26,475 jobs per year serving other economies (including the UK). In the UK, job growth in the computer services industry was very fast over the 1980s and 1990s, since 2000 the number of jobs is now fairly stable at around 566,000 jobs (in 2002). ${ }^{21}$

Overall we see an increase in jobs in business services. It is not possible to say whether this is because exports create more jobs than imports, or whether trade is neutral (or negative) with respect to job growth, but is compensated for by other factors driving growth in employment.

Sourcing business services offshore and specialisation towards business services within the UK may generate job losses in other industries that used to employ workers to do business services-type activities. A recent study by researchers at the International Monetary Fund ${ }^{22}$ on the impact of sourcing services offshore on employment growth shows that there is no significant effect of increased sourcing of services abroad on the UK on employment growth. This study is carried out at the industry level, so this suggests that jobs lost to imported inputs are compensated by job creation in the same industries.

\section{Wages}

Business Services overall is amongst the highest wage industry in the UK (it is also high skilled). In business services wages were around $£ 450$ in 2002 , compared to an average UK wage of around $£ 350$. Within business services average wages vary by industry, as shown in Figure 5. Only Other business services and Renting of Machinery show wages below the UK average.

\footnotetext{
${ }^{19}$ According to the National Association of Software and Service Companies (NASSCOM),

${ }^{20}$ Hilsenrath, J.E. (2004)

${ }^{21}$ Data from ABI, ONS. Average employment in computer services industry (SIC code 72).

${ }^{22}$ Amiti and Wei (2004)
} 
Figure 5: Average nominal weekly wage, by industry

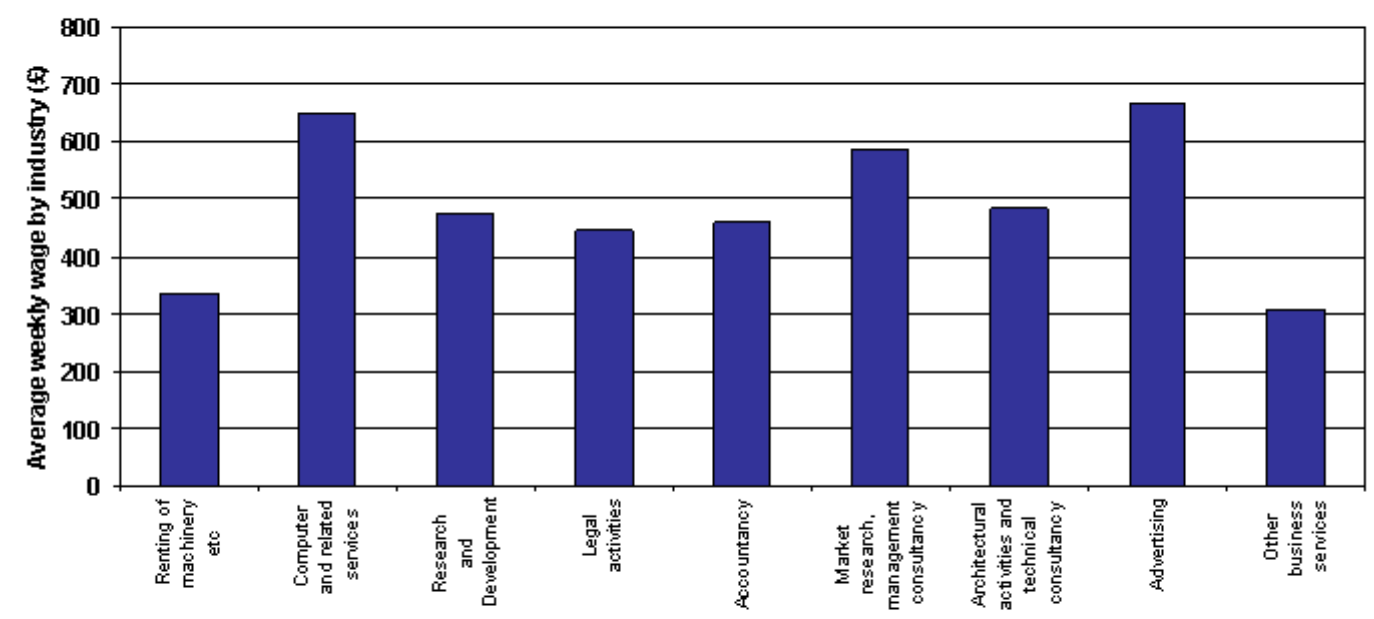

Note: Average weekly nuges are calculated considering individual's main job dassification and grossed up to the population. Year 2002. Source: authors' calculations using LFS.

\section{Productivity}

What has been happening to productivity in business services? In aggregate, business services in the UK experienced rising labour productivity levels. This is during a time when labour productivity was roughly constant in this industry in the US. This is in contrast to many other service sectors where the UK has fallen further behind the US. So while the UK still lags behind other countries, we're closing the gap, and this is happening in the relatively high skilled and high wage parts of the business service sector, where we are also showing increasing trade surpluses. ${ }^{23}$

In general, little is known about what drives productivity in services and there are many issues to do with the quality of the data. So far, the main focus of the policy and academic debate has been on the retail industry, where the UK and EU lag behind the US. This has been attributed in part to the slow uptake of ICT. It looks like Business Services in the UK is a relative success story so far. It could be that sourcing offshore and specialisation within the UK played a role in the better UK performance in

\footnotetext{
${ }^{23}$ Business services have below average labour productivity for compared to the total private sector in 2001, but this differs by sub-industry.
} 
closing the gap in business services. Recent work has shown in fact that ICT investment has been relatively high in business services in the UK. ${ }^{24}$

In terms of productivity the picture varies by industry. In computer services (Figure 7) the UK has substantially caught up with France, Germany and the US. Measuring productivity in service sectors is difficult for a number of reasons. One in particular is that we often do not have very reliable information on how prices of these services have varied over time and across countries. This is particularly important in computer services, where there have been large changes in the quality and relative price of these services. Figure 7 uses a common price index (the US computer services value-added deflator). If we use separate price indices for each country (the ones produced by each countries statistical agency) the picture looks somewhat worse for the UK. We still close the gap with the other countries but not to the same extent as shown in Figure 7. This is because the UK price index rises more steeply than in other countries. The reason we use the common US price deflator is to avoid the problem that price indices in different countries are computed using different methodologies, so reflect not only differences in actual inflation rates but also these methodological differences.

Figure 7: Value-added per hour in Computer services

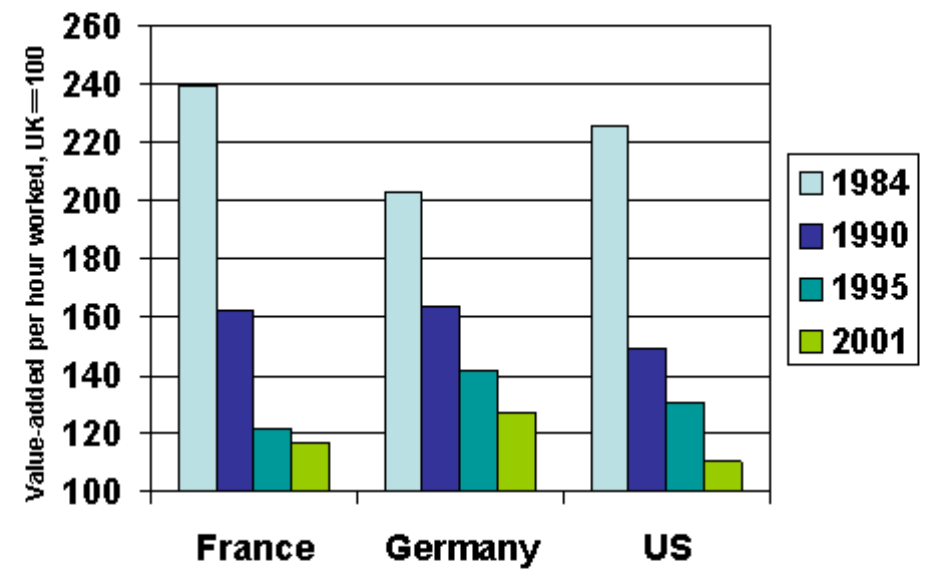

Note: Figures are calculated using PPPs for each year and US deflator.

Source: author' calculations using $G G D C$.

\footnotetext{
${ }^{24}$ Oulton, N. (2001), "ICT and Productivity Growth in the United Kingdom”, Oxford Review of Economic Policy 2002; 18:363-379
} 
In legal, technical and advertising business services the UK has completely closed the gap with Germany and the US. In fact the UK now lies ahead of Germany. A gap remains with France but it is substantially smaller now than it was two decades ago.

Figure 8: Value-added per hour in legal, accountancy, market research, technical, engineering, architectural and advertising activities and consultancy

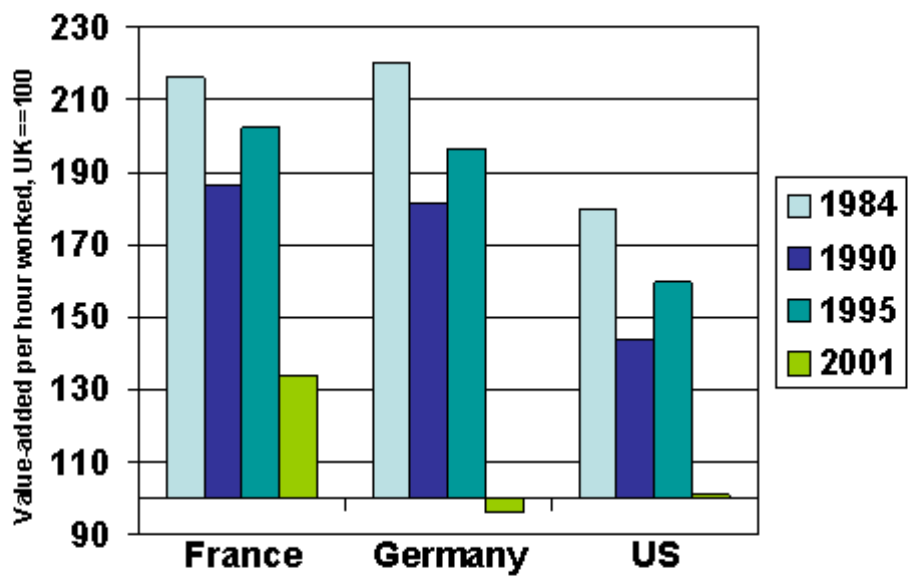

Note: Figures are calculated using PPPs for each year and US deflator. Legal, technical and advertising indude "legal activities", "accountancy", "Manket rese arch \& management consultancy", "architectural adtivities and technical consultancy" and "advertising"

Source: authors' calculations using $G G D C$. 
In other business services, international comparisons are difficult due to the varied composition of what is included in this category. However, Figure 9 indicates that the UK productivity gap has been the largest with Germany, followed by France and the US. Whilst there has been a closing of the gap with respect to Germany and France, the time trend is less clear-cut in the case of the UK-US gap.

Figure 9: Value-added per hour in other business services

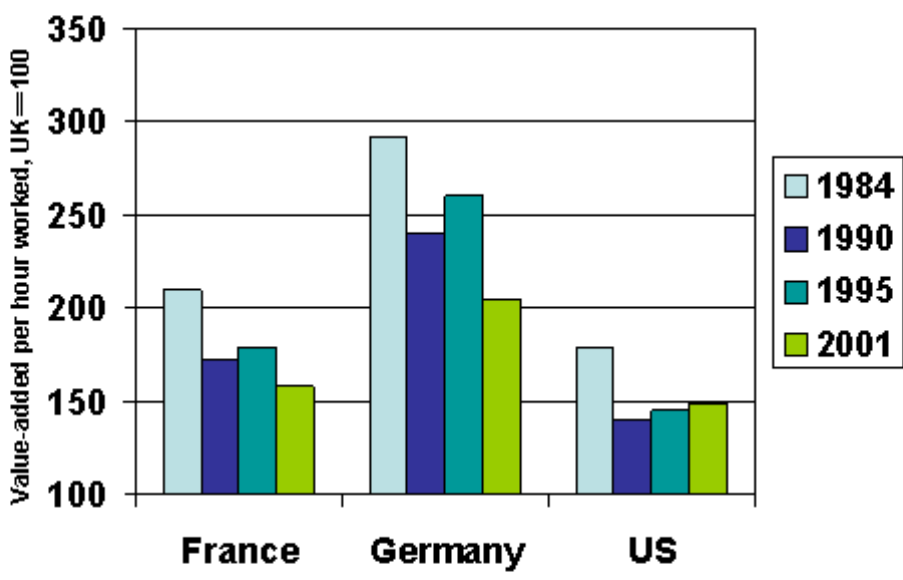

Note: Figures are calculated using PPPs for each year and US deflator. Figure 1 shows what "other business senvices" comprise. Source: authors calculations using $G G D C$. 


\section{FUTURE RESEARCH}

What might these trends mean for the future? What do policy makers need to do? What are the implications for corporate strategy and performance?

In several countries around the world there has been a move towards protectionism. The UK has traditionally been quite open, and has remained so (see World Investment Report 2004). From the figures presented here it seems that the UK has benefited from increased trade in business services. Will this continue to be the case?

In order to inform policy debate and management practice in this area, we plan to pursue further research along the following dimensions.

(a) Outsourcing and Productivity. To what extent does greater specialization through outsourcing explain rapid productivity growth in UK business services since the 1990s? Has the UK business services sector been using more ICT and better-educated labour?

(b) Impact of Offshoring on the Skill Content of UK J obs. Has offshoring led to job losses in less skilled segments of business services only, or in high skilled segments also?

(c) Impact of Outsourcing and Offshoring on the Regional Distribution of Jobs. How regionally concentrated are business service job gains and losses? How does this picture compare with manufacturing jobs?

(d) How do Companies make a Decision on What Business Services to Outsource and What to Offshore? Apart from labour cost savings, how do companies take account of upfront investment in new processes, coordination costs and risk assessment? What role does geographical distance play in developing modular or integral supply chains?

(e) What is the Impact of Outsourcing and Offshoring on Innovation in Services? Do outsourcing and offshoring contribute towards more rapid innovation through standard setting and modularization, or do they undermine innovative activities through the erosion of core competencies and knowledge base of integrated companies? 


\section{Appendix: References and Data Sources}

\section{References}

Amiti and Wei (2004), "Fear of Outsourcing: Is It Justified? ". CEPR, October 2004.

Bhagwati, Panagariya and Srinivan (2004), "The Muddles over Outsourcing". Forthcoming in The Journal of Economic Perspectives, Fall 2004.

Dornbusch, R., S. Fischer and P.A. Samuelson (1977); "Comparative advantage, Trade, and Payments in a Ricardian Model with a Continuum of Goods". The American Economic Review, Volume 67, Issue 5 (dec., 1977), 823-839

Dornbusch, R., S. Fischer and P. Samuelson (1980); "Hecksher-Ohlin Trade theory with a Continuum of Goods", Quarterly Journal of Economics, Sept. (95)2, 203-224.

DTI (2003), "Services and Offshorring: the impact of increasing international competition in services". December 2003.

Global Insight (2004) "The comprehensive impact of offshore IT software and services outsourcing on the US economy and the IT industry" sponsored by Information Technology Association of America.

Goodman, B. and R. Steadman (2002), "Services: business demand rivals consumer demand in driving job growth", Monthly Labor Review, April 2002.

Griffith, R., R. Harrison, J. Haskel and M. Sako (2003), "The UK productivity gap and the importance of the service sectors", AlM briefing note 42

Hilsenrath, J.E. (2004), “Behind Outsourcing Debate: Surprisingly Few Hard Numbers", The Wall Street J ournal Classroom, April 2004.

Oulton, N. (2001), "ICT and Productivity Growth in the United Kingdom", Oxford Review of Economic Policy 2002; 18: 363-379

Samuelson, P.A. (2004) "Where Ricardo and Mill Rebut and Confirm Arguments of Mainstream Economists Supporting Globalization". Forthcoming in The Journal of Economic Perspectives, Fall 2004.

World Investment Report (2004). The shift Towards Services. United Nations. New York and Geneva, 2004. 
World Trade Report (2004). Exploring the linkage between the domestic policy environment and international trade. World Trade Organization, Switzerland, 2004.

\section{Trade data}

We use trade data from the Input-Output tables, which are from the Balance of Payments. BoP record transactions between residents and nonresidents, the latter including affiliates residing in the rest of the world. In business services pretty much all trade is between firms, and hence ofr intermediate consumption - in 1995 97\% of imports of business services were between firms.

We deflate import and export values using the UK Gross Domestic Product deflators. The picture is similar if we use a service sector value-added deflator.

For the cross-country comparisons we use WTO (2003) International Trade Statistics 2003, Trade by sector, http://www.wto.org/english/res_e/statis_e/its2003_e/its03_bysector_e.ht $\mathrm{ml}$

\section{I nput Output data}

We use Input-Output Tables from 1984 and 2001. The Standard Industrial Classification of industries change during that time period. We use the Domestic Use Table at basic prices. In order to do this we have to transform the 2001 Combined Use Tables at purchasers prices using information from the 1995 Input-Output Tables.

In Table 1, sic codes 70 and 67 are included in Business services and 73 in Public administration.

\author{
Sector \\ Agriculture, Mining and Quarrying \\ Manufacturing \\ Electricity, gas and water \\ Construction \\ Wholesale and retail \\ Hotels and restaurants \\ Transport and communications \\ Financial intermediation \\ Business services \\ Public administration and other
}

Sic codes
$01-14$
$15-37$
$40-41$
45
$50-52$
55
$60-64$
65,66
$67,70,71,72,74$
$73,75-99$

Sic codes

$15-37$

40-41

$50-52$

55

65,66

73, 75-99 


\section{Productivity Data}

To calculate labour productivity we use value-added at basic prices deflated by the US industry value-added deflator converted using PPPS for GDPHistorical series from the OECD (http:/www.oecd.org/std/ppp/). We also use data on hours worked. These come from the GGDC database (http://www.ggdc.net/dseries/60-industry.html).

\section{Other Data}

We use data from Incomes Data Services Pay and Condition Report on Call Centres (2004), http://www.incomesdata.co.uk/report/callcentpressrel.htm. The data comes from a survey of 107 organisations employing around 92 thousands call centre staff.

\section{Growth Decomposition}

The figures reported in Table 1 in the main text are from a decomposition of total UK output growth. The decomposition is given by:

$$
\Delta Y_{k t}=\sum_{j} \Delta Y_{j t} S_{j k 1}+\sum_{j} Y_{j 1} \Delta S_{j k t}+\sum_{j} \Delta Y_{j t} \Delta S_{j k t}+\Delta G F C F_{k}+\Delta X_{k}+\Delta R_{k} .
$$

where $\mathrm{Y}$ : output, $\mathrm{j}$ : producer industry, $\mathrm{k}$ : supplier industry, $\mathrm{S}$ : share of good $k$ in costs of production of $j$, GFCF: investment, $X$ : exports, R: final demand.

The full decomposition for all industries is shown in Table A.1 
Table A.1: Share of growth in UK Output, 1984-2001

\begin{tabular}{|c|c|c|c|c|c|c|}
\hline & $\begin{array}{c}(1) \\
\text { Purchases by } \\
\text { UK-based } \\
\text { firms }\end{array}$ & $\begin{array}{c}(2) \\
\text { of which } \\
\text { specialisation } \\
\text { and } \\
\text { outsourcing }\end{array}$ & $\begin{array}{c}\text { (3) } \\
\text { Purchases by } \\
\text { foreign-based } \\
\text { firms (exports) }\end{array}$ & $\begin{array}{l}(4) \\
\text { Other }\end{array}$ & $\begin{array}{c}\text { Total }= \\
(1)+(3)+(4)\end{array}$ & Imports \\
\hline \multicolumn{7}{|l|}{ Production } \\
\hline Manufacturing & $0.3 \%$ & $-4.2 \%$ & $7.5 \%$ & $-0.4 \%$ & $7.4 \%$ & $9.8 \%$ \\
\hline Electricity, gas and water supply & $1.1 \%$ & $0.4 \%$ & $-0.1 \%$ & $-0.4 \%$ & $0.7 \%$ & $0.0 \%$ \\
\hline Construction & $5.3 \%$ & $0.9 \%$ & $0.0 \%$ & $-0.6 \%$ & $4.7 \%$ & $0.0 \%$ \\
\hline \multicolumn{7}{|l|}{ Services } \\
\hline Wholesale and retail trade & $3.4 \%$ & -- & $1.8 \%$ & $8.5 \%$ & $13.7 \%$ & $-0.1 \%$ \\
\hline Hotel and Restaurants & $0.6 \%$ & $0.3 \%$ & $0.3 \%$ & $3.1 \%$ & $4.0 \%$ & $0.7 \%$ \\
\hline Transport and communication & $7.5 \%$ & $1.9 \%$ & $0.0 \%$ & $1.7 \%$ & $9.1 \%$ & $-0.2 \%$ \\
\hline Financial intermediation & $4.7 \%$ & $2.4 \%$ & $0.2 \%$ & $2.3 \%$ & $7.3 \%$ & $0.1 \%$ \\
\hline Business Services and real estate & $19.5 \%$ & $6.5 \%$ & $3.7 \%$ & $8.8 \%$ & $32.0 \%$ & $1.7 \%$ \\
\hline $\begin{array}{l}\text { Public administration and other } \\
\text { services }\end{array}$ & $10.2 \%$ & $3.6 \%$ & $0.8 \%$ & $12.4 \%$ & $23.4 \%$ & $0.6 \%$ \\
\hline Total & $50.9 \%$ & $9.9 \%$ & 13.2 & $35.9 \%$ & $100.0 \%$ & $12.2 \%$ \\
\hline \multicolumn{7}{|c|}{$\begin{array}{l}\text { Notes: } \\
\text { (1) Share of the total increase in UK output that was accounted for by increased purchases by other businesses in the UK, including capital } \\
\text { goods. The increase in purchases could be because the firms have grown in size and so now need more business services, or because they } \\
\text { now use these specialised business services more intensively. } \\
\text { (2) is part of (1). It is the increase in firms' purchases of business services that is driven by an increased intensity of usage of business } \\
\text { services produced in specialised plants or offices, in order to produce the same amount of output that they were producing in } 1984 \text {. } \\
\text { (3) Share of the total increase in UK output that was accounted for by an in increase purchases of business services by foreign-based } \\
\text { firms, that is an increase in exports of business services. } \\
\text { (4) Share of the total increase in UK output that was accounted for by changes in purchases of business services by consumers and } \\
\text { government. } \\
\text { Total is the sum of rows (1), (3) and (4). It is the share of the total increase in UK output accounted for by Business Services. } \\
\text { Final row is growth of imports by sector as a proportion of growth in total output. }\end{array}$} \\
\hline
\end{tabular}




\section{Acknowledgements}

The authors would like to thank Panayotis Dessyllas, Rupert Harrison, Jonathan Haskel, Gerard Hodgkinson, Helen Simpson, Abigail Tierney, Romesh Vaitilingam and Chris Voss, as well as participants in an earlier workshop at the IFS in May 2004 for discussion and comments. This Briefing Note has been written with financial support from the ESRC through the AIM initiative. All errors and omissions remain the responsibility of the authors. 